\title{
MÓJ MISTRZ, NAUCZYCIEL, WYCHOWAWCA
}

\author{
Michał Pluciński \\ Wydział Zarządzania i Ekonomiki Usług, Uniwersytet Szczeciński
}

\begin{abstract}
Nie raz i nie dwa w trudnych chwilach swojego młodzieńczego życia sięgałem po sienkiewiczowskie Ogniem i mieczem. Zawsze czytałem ten sam fragment bitwę pod Zbarażem (taki rodzaj nieszkodzącego zdrowiu dopalacza). Jeszcze wtedy nie wiedziałem jednak jak ważną rolę w moim życiu odegra jeden zbarażczyk, z postury całkowicie nieprzypominający Longinusa Podpipięty.
\end{abstract}

Nie pamiętam czy nad wyborem promotora myślałem długo, czy była to szybka decyzja. Pamiętam natomiast doskonale, że początek transformacji nie był najlepszym czasem dla transportu morskiego (studia zaczynałem w 1993 r.). Ta gałąź transportu przez większość moich koleżanek i kolegów traktowana była jako coś w rodzaju reliktu przeszłości. Większość z nich chciała trafić na seminaria do innych niż morska katedr. W kolejnych miesiącach okazało się jednak, że to ja nie traktowałem spotkań seminaryjnych jako tzw. zła koniecznego.

Na początku seminariów podszedłem do nich podobnie jak większość studentów - trzeba przyjść i swoje odsiedzieć. Zdolność Profesora Franciszka Gronowskiego do bardzo ciekawego przedstawiania problematyki funkcjonowania i rozwoju polskiego transportu morskiego spowodowała jednak, że zacząłem bardziej uważnie przysłuchiwać się wykładom promotora. Do dzisiaj pamiętam jak Profesor przedstawiał sprawę aresztowań statków PŻM w zagranicznych portach morskich po ogłoszeniu w Polsce stanu wojennego oraz szybkie powołanie spółki Żegluga Polska SA, do której flota ta została przekazana. Ujmował nas nie tylko swoją ogromną wiedzą i identyfikowaniem się z losami polskiego transportu morskiego, ale również wysoką kultura osobistą i szacunkiem z jakim traktował studentów. Imponowało nam również to, że nasz promotor „nie spinał się” w trakcie spotkań, wręcz przeciwnie - zawsze cechował Go naturalny luz. Nie był to jednak luz lekkoducha, który nie traktuje poważnie omawianej tematyki. Chodzi raczej o taki luz rozładowujący naturalną barierę jaka dzieli profesora od jego seminarzystów. W momencie przechodzenia do omawiania tematyki wykładu żarty się kończyły, gdyż Profesor edukację kolejnych pokoleń studentów traktował jako fundament pracy akademika.

Ważnym elementem współpracy w ramach seminariów był wybór tematu przyszłej pracy magisterskiej. Z propozycji przedstawionych grupie przez Promotora początkowo myślałem 
o tematyce funkcjonowania jednej z ówczesnych spółek PŻM (Polstem Tankers). Profesor Franciszek Gronowski przekonał mnie jednak, że mały port Stepnica, w którym doszło do pierwszego w Polsce przypadku komunalizacji terenów portowych, może być nie mniej ciekawym i ambitnym wyzwaniem badawczym. Wakacyjny wyjazd do Stepnicy, dwutygodniowy pobyt $\mathrm{w}$ tej nadzalewowej gminie, wywiady przeprowadzane z przedstawicielami samorządu gminnego oraz podmiotów związanych z użytkowaniem terenów portowych, dzisiaj postrzegam jako pierwsze kroki w realizacji pierwotnych badań naukowych.

Profesor Franciszek Gronowski wprowadził mnie do katedry morskiej (wtedy katedry Gospodarki Morskiej), którą kierował prof. K. Luks (trochę na odległość z uwagi na obowiązki ministerialne). Pamiętam jak Profesor Franciszek przekonywał szefa do zatrudnienia nowego pracownika: „Krzysiu dawno nie miałeś asystenta”, na co prof. K. Luks szczerze odpowiedział „wreszcie ktoś pozmywa te brudne szklanki”.

Profesor Franciszek Gronowski wspierał mnie podczas pierwszych publicznych wystąpień. To dzięki Niemu, jednemu z inicjatorów i liderów regularnych spotkań ludzi morza, uzyskałem status „Dziecka Sejmików Morskich”. Doskonale pamiętam swoje pierwsze wystąpienie na Sejmiku Morskim w Kamieniu Pomorskim. Bardzo przeżywałem dyskusję, która wywiązała się po trochę przydługawej prelekcji (trzykrotnie byłem przywoływany dzwonkiem do jej zakończenia!). Mój Mistrz skutecznie wytłumaczył mi, że dyskusja nad wystąpieniem jest czymś całkowicie normalnym, a wręcz pożądanym (coś kogoś w nim przecież zainteresowało). Po kilku latach pomyślałem, że zaproponuję Profesorowi przygotowanie wspólnej publikacji. Odpowiedział wtedy z uśmiechem na twarzy, że przecież już dawno scedował na mnie swoją aktywność publikacyjną. Oczywiście nie oznaczało to całkowitego końca aktywności Profesora, szczególnie jako prelegenta i wiodącego dyskutanta w trakcie seminariów, konferencji i kolejnych sejmików. Należy podkreślić, że głos Profesora nigdy nie jest „jałowy”, każdą wypowiedź kończy syntetycznymi wnioskami kierowanymi do konkretnych adresatów. Krytycznie ocenia zmiany w obszarze polskiej gospodarki morskiej jakie nastąpiły po transformacji systemowej i wycofaniu się państwa z prowadzenia polityki morskiej. Dostrzega jednak nowe możliwości kreowania tejże polityki przez samodzielne i niezależne samorządy lokalne. Zawsze formułuje odważne, ale i racjonalne tezy. Słowa krytyki w jego ustach nigdy nie mają charakteru krytyki dla samego krytykowania. Dużą uwagę przywiązuje do czynnika ludzkiego, podkreślając, że za każdym działaniem stoi konkretny człowiek.

Przez cały dotychczasowy okres swojej pracy na uczelni mogłem liczyć na dobre rady Profesora. I nie chodzi tylko o stronę merytoryczną publikacji czy sprawy dydaktyczne. Profesor zawsze przywiązywał dużą wagę do współpracy z praktyką gospodarczą i administracją publiczną. Przestrzegał jednak przed angażowaniem się w przygotowanie opracowań, których inicjatorzy z góry ustalali wyniki końcowe badań. Nigdy nie zapomnę też, gdy przy okazji kolejnego spotkania na wydziałowym korytarzu Profesor zaskoczył mnie uwagą "Michał, fajny z ciebie chłopak, ale za dużo przepraszasz i za dużo dziękujesz”. W pierwszej chwili zdziwiła mnie ta uwaga, szczególnie, że usłyszałem ją od człowieka o najwyższej w mojej ocenie kulturze osobistej. Z czasem zrozumiałem co Profesor chciał mi przekazać.

Los sprawił, że moja współpraca z Profesorem Franciszkiem Gronowskim jako Promotorem objęła również etap doktoratu. Co prawda początkowo ustalenia były takie, że rolę promotora pełnić będzie prof. K. Luks, a następnie (po pomyślnie zakończonym kolokwium habilitacyj- 
nym) przejmie ją dr H. Salmonowicz. Na wniosek zgłoszony podczas posiedzenia Rady Wydziału przez prof. W. Grzywacza przewód doktorski został otwarty, ale bez wyznaczenia osoby promotora. Profesor W. Grzywacz zasugerował, że młodym adeptem próbującym zbadać dość dziewiczy w Polsce obszar związków miasto-port morski powinien zaopiekować się doświadczony i często odwiedzający mury wydziału promotor. Sugestia skierowana była do Profesora Franciszka Gronowskiego, który (na moje szczęście) zgodził się podjąć to wyzwanie. Współpraca ta zakończyła się pełnym sukcesem, którego zwieńczeniem była pomyślna obrona pracy doktorskiej w 2002 roku.

Pomimo przebywania na „emigracji” w Bydgoszczy Profesor nadal wspierał mnie w aktywności akademickiej oraz w działalności na rzecz praktyki gospodarczej. Odegrał również ważną rolę w moim ostatnim awansie naukowym. Rada Wydziału nie dostrzegając w swoim gronie osoby z odpowiednim dorobkiem naukowym w obszarze problematyki ekonomiki i organizacji transportu morskiego podjęła decyzję, że rolę recenzenta mojego dorobku habilitacyjnego, obok prof. A.S. Grzelakowskiego z Akademii Morskiej w Gdyni, powierzy właśnie Profesorowi Franciszkowi Gronowskiemu.

Stres związany z obroną habilitacyjną spowodował, że publicznie nie wyraziłem swojej ogromnej wdzięczności mojemu Mistrzowi za wszystkie lata naszej współpracy. Dzięki publikacji jubileuszowej dostaję możliwość naprawienia tego przeoczenia. Jak napisałem w monografii nawiązującej do jubileuszu 75-lecia urodzin Profesora Franciszka Gronowskiego „Plany czynione bez porady nie powiodą się. Dzięki dobrym doradcom zawiodą do celu”. Ta maksyma wypowiedziana przez Króla Salomona, w najlepszy sposób oddaje moje odczucia związane $\mathrm{z}$ rolą jaką Jubilat odegrał w moim dorosłym życiu, w tym przede wszystkim w ukształtowaniu mnie jako badacza, dydaktyka uczelnianego, czy po prostu - lepszego człowieka.

Panie Profesorze - dziękuję, że stanął Pan na mojej drodze! 